This item was submitted to Loughborough's Research Repository by the author.

Items in Figshare are protected by copyright, with all rights reserved, unless otherwise indicated.

\title{
Entrepreneurial marketing decision-making in rapidly internationalising and de-internationalising start-up firms
}

PLEASE CITE THE PUBLISHED VERSION

https://doi.org/10.1016/j.jbusres.2018.11.033

PUBLISHER

(C) Elsevier

VERSION

AM (Accepted Manuscript)

\section{PUBLISHER STATEMENT}

This paper was accepted for publication in the journal Journal of Business Research and the definitive published version is available at https://doi.org/10.1016/j.jbusres.2018.11.033.

LICENCE

CC BY-NC-ND 4.0

\section{REPOSITORY RECORD}

Crick, Jim, David Crick, and Shiv Chaudhry. 2018. "Entrepreneurial Marketing Decision-making in Rapidly Internationalising and De-internationalising Start-up Firms". Loughborough University.

https://hdl.handle.net/2134/36193. 


\title{
Entrepreneurial Marketing Decision-Making in Rapidly Internationalising and De-Internationalising Start-up Firms
}

\author{
James M. Crick, Dave Crick and Shiv Chaudhry
}

\section{Address for Correspondence:}

Dave Crick, University of Ottawa, Telfer School of Management, Ontario K1N 6N5 Canada. Email: dcrick@uottawa.ca; Tel: +1 6135625800 Ext. 4916

Biography: James M. Crick is a Lecturer in Marketing at the Business School, Loughborough University, UK. His current research interests involve work in Entrepreneurial Marketing and International Strategy; particularly work that addresses competitiveness.

Biography: Dave Crick is the Paul Desmarais Professor of International Entrepreneurship and Marketing in the Telfer School of Management at the University of Ottawa, Canada. His current research interests involve work at the Marketing/International Entrepreneurship interface and particularly work that addresses a more effective public/private sector interaction.

Biography: Shiv Chaudhry is Professor of Marketing and International Business at the Business School, Birmingham City University, UK. His current research interests involve work at the Marketing/International Entrepreneurship interface and particularly work involving ethnic minorities.

Classification: Research Paper. Special Issue 30 Years of EM; Guest Editor Fabian Eggers.

\begin{abstract}
This study utilises an effectuation lens to contribute to knowledge involving the entrepreneurial marketing practices of rapidly internationalising firms, following a temporary discontinuation of overseas sales. This is important since earlier studies typically focus on continuing overseas activities, not de-internationalisation. Semi-structured interviews took place with owner-managers of sixteen small, UK based, knowledge-intensive start-ups, before planned re-internationalisation occurred. All management teams were proactive, took risks, exploited innovation and engaged in opportunity-driven plus resource leveraging behaviour. Conversely, creating adequate 'customer value' did not occur. The investigation highlights that in particular contexts, certain facets of an effectuation approach outweigh others and the notion of 'affordable losses' is viewed in both financial and non-financial terms. The study offers unique insights into the need for decisionmakers in rapidly internationalising firms to undertake validation of strategies to discover new customers; also, the potential usefulness to lose particular customers, even temporarily, to facilitate enduring entrepreneurial marketing activities.
\end{abstract}

Keywords: De-Internationalisation; Effectuation; Entrepreneurial Marketing; Rapid Internationalisation. 


\title{
Entrepreneurial Marketing Decision-Making in Rapidly Internationalising and De-Internationalising Start-up Firms
}

\begin{abstract}
This study utilises an effectuation lens to contribute to knowledge involving the entrepreneurial marketing practices of rapidly internationalising firms, following a temporary discontinuation of overseas sales. This is important since earlier studies typically focus on continuing overseas activities, not de-internationalisation. Semi-structured interviews took place with owner-managers of sixteen small, UK based, knowledge-intensive start-ups, before planned re-internationalisation occurred. All management teams were proactive, took risks, exploited innovation and engaged in opportunity-driven plus resource leveraging behaviour. Conversely, creating adequate 'customer value' did not occur. The investigation highlights that in particular contexts, certain facets of an effectuation approach outweigh others and the notion of 'affordable losses' is viewed in both financial and non-financial terms. The study offers unique insights into the need for decisionmakers in rapidly internationalising firms to undertake validation of strategies to discover new customers; also, the potential usefulness to lose particular customers, even temporarily, to facilitate enduring entrepreneurial marketing activities.
\end{abstract}

Keywords: De-Internationalisation; Effectuation; Entrepreneurial Marketing; Rapid Internationalisation. 


\section{Entrepreneurial Marketing Decision-Making in Rapidly Internationalising and De-Internationalising Start-up Firms}

\section{Introduction}

\subsection{Research Objective}

Hills \& Hultman (2011, p. 3) view entrepreneurial marketing (EM) “as a spirit, an orientation as well as a process of passionately pursuing opportunities and launching and growing ventures that create perceived customer value through relationships by employing innovativeness, creativity, selling, market immersion, networking, and flexibility”. Whalen et al (2016) suggest that EM arises from the practices of firms operating under conditions of uncertainty, providing an alternative to the traditional marketing perspective. Nevertheless, many start-up firms fail given the relative conditions of uncertainty in which they operate (Blank, 2013); hence, the issue of 'context' is important in considering firms' behaviour, since unique insights from particular contexts can contribute to knowledge (Jones \& Rowley, 2011; Reuber et al., 2017). In fact, Morris et al. (2002, p.1) note: "marketing is context dependent, but the context is continually changing". In this current study, 'de-internationalisation' provides an interesting context in which to study EM behaviour, given the potential risk or even uncertainty surrounding new ways of operating in overseas markets (Liesch et al., 2011; Vahlne et al., 2017; Crick \& Crick, 2018a).

Earlier studies drawing on aspects of entrepreneurial orientation and market orientation exist that involve serving overseas markets and de-internationalisation in line with the context of this current investigation (Rose \& Shoham, 2002; Bhuian et al., 2005; Yayla et al., 2018). Levels of uncertainty and potential risks affecting internationalisation differ across firms in respect of a variety of resources/capabilities and economic/competitiveness factors (Crick, 2004; Yayla et al., 2018). Such conditions potentially affect management teams' decision-making and the perceived performance of firms operating in new institutional environments with their own cultures and regulations (Spence \& 
Crick, 2006). Debate exists in earlier research involving terminology regarding 'uncertainty' and 'risk' (Saravathy, 2001; McKelvie et al., 2011). In this current study, the term 'risk' in respect of decision-makers' perceptions is purposefully used. Specifically, because 'uncertainty' in earlier research is largely viewed as when a decision-maker cannot assign probability to various outcomes, whereas 'risk' implies he/she can act on some probability towards outcomes occurring, like via research and experience. In addressing potential risks, seminal earlier research such as Johanson \& Vahlne (1977) discuss an incremental approach to internationalisation based on increasing knowledge and commitment.

In contrast, factors like the need to gain first mover status to exploit 'windows of opportunity', obtain resources from stakeholders like incubators and grant awarding bodies, and the recent influence of the Internet in gaining information and facilitating unsolicited orders, suggest some firms internationalise rapidly (Oviatt \& McDougall, 1994; Knight \& Cavusgil, 2004; Hewerdine et al., 2014; Crick \& Crick, 2018a). Prior studies have used different terms such as 'international new ventures' (INVs) and 'born globals' to classify rapidly internationalising firms and hence no single agreed set of criteria exist to categorise their speed, scale and scope of overseas market activities (Crick \& Crick, 2014; Coviello, 2015). This current study hereafter uses the term 'INVs' to categorise the firms under investigation given that first, in terms of 'speed', they had internationalised rapidly. However, second, their ratio of exports to total sales (scale of internationalisation) was low; and third, their scope (or geographical coverage) of overseas markets served before de-internationalisation took place was limited, such as, to a particular market like the US. Consequently, it would be difficult to claim they were 'born global' in respect of commitment to overseas sales and the number of markets served.

Nevertheless, although a body of literature exists involving INVs' early internationalisation activities, relatively few studies exist concerning INVs' continuing behaviour (Morgan-Thomas \& 
Jones, 2009; Spence \& Crick, 2009; Ibeh et al., 2018). In fact, a gap exists in the literature regarding the practices of those INVs that quickly withdrew from overseas markets as opposed to remaining engaged in international activities. This current study addresses that gap by considering facets of INVs' EM behaviour to facilitate enduring activities after overseas market withdrawal took place and prior to planned re-internationalisation occurring. In other words, it considers EM decisionmaking in a 'time-out' contextual period (between overseas market withdrawal and international market re-entry) used to re-evaluate strategies (Hadjikhani, 1997; Crick \& Chaudhry, 2006; Welch \& Welch, 2009). It is therefore an under-researched context and not least due to the difficulty in locating and facilitating access to decision-makers at this stage of firms' development. A number of studies exist to indicate firms enter and exit product-markets; that is, internationalisation is not always a forward moving process (Bell et al., 2003; Crick, 2004; Turner, 2012; Bernini et al., 2016; Yayla et al., 2018). However, insights into this behaviour appear somewhat limited and hence this current study is timely and addresses an important gap in the literature, since it involves decisionmaking in INVs that rapidly de-internationalised and follows a recent call for more research (Yayla et al., 2018).

On the one hand, it seems somewhat counter intuitive for start-ups to enter overseas markets rapidly only to then quickly de-internationalise, namely, if there are identified opportunities. For example, behaviour might include pursuing the previously mentioned opportunities of first mover status, access to resources etc. (Crick \& Crick, 2014; Hewerdine et al., 2014). On the other hand, market withdrawal appears consistent with the recognised need to pivot strategies if required; such as, reacting to customer feedback and market conditions (Osterwalder \& Pigneur, 2010; Ries, 2011; Gassmann et al., 2014). De-internationalisation is also potentially consistent with 'The Affordable Loss Principle' of an effectuation lens (Sarasvathy, 2001). Specifically decision makers in underresourced set-up firms do not always focus on possible profits, but minimising potential losses 
before limited funds are used (Crick \& Crick, 2018b). Such considerations within earlier literature lead to the study's research question as follows:

$R Q:$ What role does EM-oriented decision-making play for management teams in INVs that have rapidly withdrawn from overseas markets?

\subsection{Contribution}

In contributing to the existing knowledge of INVs' enduring EM behaviour, this study draws on the seven facets of EM behaviour mentioned by Morris et al. (2002). These involve a proactive orientation, opportunity-driven behaviours, customer intensity, innovation-focused behaviours, riskmanagement, resource leveraging behaviours and value creation. By utilising an effectuation lens as an academic underpinning, we broadly offer support for Sarasvathy's (2001) seminal research and find aspects of all five facets of the effectuation approach evident to some degree in entrepreneurs' decision-making (see also, Prashantham et al., 2018). Our first contribution is to highlight that in particular contexts, a certain element of the effectuation lens can dominate decision-making. In the specific context of this current study, entrepreneurs focused on 'The Affordable Loss Principle' in the de-internationalisation decision. Other elements of effectuation decision-making were more evident within initial internationalisation and later potential re-internationalisation considerations. The second contribution is to highlight different dimensions of the notion of entrepreneurs' perceived 'affordable loss'. These dimensions vary in respect of the influence of different stakeholders like customers and network partners, namely, in both potential financial (like profits/losses) and non-financial (such as credibility) terms.

We thirdly contribute to the knowledge by indicating how the different facets of EM need to come together to help facilitate enduring EM behaviour in the customer discovery process within new product-markets. In light of risk/reward considerations, we show that all the management teams had a proactive mind-set, took risks, exploited innovation, and engaged in opportunity driven plus 
resource leveraging behaviour (entrepreneurial-oriented facets of EM behaviour). However, decision making that paid lip service to 'all' aspects of EM was also evident. By moving too rapidly without adequate preparation, such as, accepting serendipitous orders, none of the decision-makers fully understood customer expectations or created value (marketing-oriented facets of EM behaviour). This EM behaviour led to temporary overseas market withdrawal and the need to reevaluate strategies vis-a-vis perceived risks/rewards and affordable losses. In short, this study offers unique insights into the need for decision-makers in rapidly internationalising firms to undertake validation of strategies to discover new customers. Additionally, why it is potentially useful for management teams in particular rapidly internationalising start-up firms to lose some international customers, even temporarily, to facilitate enduring EM activities; an issue somewhat counter intuitive to certain existing studies.

\section{Literature Review}

\subsection{The EM Domain}

The last few decades have witnessed a body of knowledge emerge involving EM as a distinct research domain within the broader entrepreneurship and marketing literature (Hills \& LaForge, 1992; Morris et al., 2002; Hills et al., 2008; Morrish et al., 2010; Miles et al., 2014; Whalen et al., 2016). For example, Whalen et al. (2016) note that rapid changes in technology and customer preferences create conditions of uncertainty potentially rendering traditional marketing strategies and tactics as less effective. They proceed to suggest that EM attempts to merge particular relevant insights from both entrepreneurship and marketing. Nevertheless, Hansen \& Eggers (2010) note that perspectives within the EM domain have varied leading to differences in respective findings regarding the employment of EM in practice. That is, existing studies view EM from the perspectives of the following: commonalities between disciplines, entrepreneurship factors viewed 
through a marketing lens, marketing issues via an entrepreneurship lens, and unique perspectives evolving from a combination of entrepreneurship and marketing.

Various definitions exist involving EM (such as Morris et al., 2002; Hills \& Hultman, 2011). However, returning to that used by Hills \& Hultman (2011) cited earlier in this paper, the issue of "launching and growing ventures" is relevant since EM activities can exist in larger firms after a growth period (Miles \& Darroch, 2006). Additionally, Kilenthong et al. (2016) suggest EM should not be conceptualised solely in respect of the behaviour of small firms, young firms or founder operated firms. Moreover, the definition by Hills \& Hultman (2011) does not necessarily imply profitability, since EM behaviour can also exist in not-for-profit ventures (Roundy, 2017). This is noteworthy since the EM literature depicts a type of behaviour and is not restricted to businesses with commercial goals, but can also apply to organisations with objectives of a 'social' nature. Nevertheless, this current study involves start-up firms with commercial goals.

Morrish (2011) points out that EM is perhaps best articulated not as a nexus between entrepreneurship and marketing, but what is seen as an augmented process; namely, where both the entrepreneur and customer are the core participants, co-creating value within the marketing environment (consistent with Morrish et al., 2010). Whalen \& Akaka (2016) suggest opportunities are continually co-created; that is, via the derivation and determination of value and the reformation of markets. In the context of this current study, the environmental risks associated with initial internationalisation provides potential difficulties to co-create this value unless appropriate validation exists (Osterwalder \& Pigneur, 2010; Ries, 2011; Gassmann et al., 2014). Zhu \& Matsuno (2016) find that firms are most likely to employ EM strategies in high-growth, highly dynamic environments. This finding is consistent with the context of this current study whereby internationalisation offers growth potential in dynamic environments (Crick \& Crick, 2014; 2016), 
assuming evolving business models are validated by decision makers as an iterative process to find the appropriate product-market fit (Hansen et al., 2018).

Ahmadi \& O'Cass (2016) focus on EM activities via the degree of complementarity between entrepreneurial orientation and market orientation in driving innovation in respect of new technology ventures' first product commercialisation. They find a positive effect regarding exploratory and exploitative activities in enhancing performance; also, the contingency role of marketing capabilities. However, EM initiatives to build capabilities and consequently leading to performance enhancing strategies vary across decision makers (Bell et al., 2003; 2004). As Eggers et al. (2012, p.203) point out "strategies cannot come out of nowhere". In fact, both planned and unplanned decision-making feature in earlier export related studies (Spence \& Crick, 2006; Crick \& Crick, 2014; 2016; 2018a). Furthermore, Mirvahedi \& Morrish (2017) discuss the notion of 'entrepreneurial serendipity' and find behaviour characterised by entrepreneurs finding an unspecified opportunity via an orderly or haphazard search, that might happen with either high or low levels of knowledge. In short, understanding EM decision-making in formulating strategies within particular contexts provides useful insights. Hills \& Hultman (2011) in their research summarising the academic roots plus the past and present of EM, suggest that the development of effectuation theory (Sarasvathy, 2001) helps scholars to understand decision-making in light of conditions of risk/uncertainty and, consequently, important aspects of EM behaviour. It therefore appears an appropriate lens in this current study.

\subsection{Effectuation Oriented Decision-Making}

As previously mentioned, the theoretical lens in this investigation involves 'effectuation' oriented decision-making (Sarasvathy, 2001). 'The Bird in Hand Principle' suggests entrepreneurs start with what they have and look at who they are, what they know and who they know. 'The Affordable Loss Principle' involves an entrepreneur not focusing on the upside, like profits; rather, whether the 
downside is acceptable, like minimising potential losses. 'The Crazy Quilt Principle' involves entrepreneurs cooperating with partners to commit to jointly affecting future strategies. 'The Lemonade Principle' is when entrepreneurs will look at how to leverage contingencies; for example, are they flexible to surprises that offer potential opportunities. 'The Pilot-in-the-Plane' involves putting the previous principles together. In essence, it follows that entrepreneurs cannot predict the future; however, they can control certain factors that help determine the future. Debate nevertheless exists over Sarasvathy's (2001) research in respect of the merits of the causation versus effectuation approaches (Arend et al., 2015; Read et al., 2016).

Causation based decision-making could begin with various alternatives and end in one objective; however, effectuation based decision-making has the realisation that these alternatives can end in different ways (Sarasvathy, 2001). Causation based decision-making is considered more effective in predictable environments and effectuation based decision-making where the future is unpredictable (Andersson, 2011). Some earlier studies involving internationalising firms are underpinned by an effectuation approach (Andersson, 2011; Gabrielsson \& Gabrielsson, 2013; Kalinic et al., 2014; Chetty et al., 2015; Galkina \& Chetty, 2015; Yang \& Gabrielsson, 2017; Prashantham et al., 2018). For example, Andersson (2011) mentions issues like 'what' the entrepreneur in an internationalising firm knows and 'who' they know. This may be important in under-resourced start-up firms that need to draw on the capabilities of their small management team that includes knowledge/experience from prior employment and networks. In fact, Galkina \& Chetty (2015) highlight the importance of networks, while Crick \& Crick (2018b) suggest for under-resourced start-up firms, new network partners like investors can enhance decision-makers' resources and capabilities in light of an unpredictable environment. Recently, Prashantham et al. (2018) draw on all five principles of effectuation and identify 'internationalisation speed' as an important outcome variable. 


\subsection{De-Internationalisation and Potential Re-Internationalisation}

Studies have largely focused on internationalisation as an outward and increasing process (Jones et al., 2011), underpinned by learning and increased commitment over time (Jones \& Coviello, 2005). In contrast, de-internationalisation, can involve a reduction of commitment in various respects based on decision-makers' perceptions. For example: reducing overseas activities, stopping these activities, or firms moving in and out of various markets (Benito \& Welch, 1997; Pauwels \& Matthyssens, 2004; Javalgi et al., 2010; Turner, 2012; Bernini et al., 2016; Yayla et al., 2018). Drawing on the issue of co-evolution theory, Turner (2012) highlights different paths of contraction and expansion followed by firms; trajectories are not pre-determined and hence various issues influence these for respective management teams. Such an approach appears consistent with effectuation-based decision-making.

Benito \& Welch (1997) argue that de-internationalisation as an outcome results from a set of factors linked to past international operations and commitments; also, current developments within and external to the company. Nevertheless, 'past' activities may vary between firms and those in this current study involved rapidly internationalising start-ups with limited experience among management teams. Therefore, consistent with Hansen et al. (2018) in respect of EM behaviour, understanding validation efforts to find the appropriate product-market fit is useful. Welch \& Wiedersheim-Paul (1980) suggest that withdrawal from international markets is not necessarily a market failure; it depends on a decision-maker's objectives. This is relevant to this current study, since decision-makers may formulate strategies based on objectives other than just sales like securing funding (Hewerdine et al., 2014; Crick \& Crick, 2018b). Moreover, decision-makers' objectives can change over time (Spence \& Crick, 2006).

Welch \& Welch (2009, p.567) consider the re-internationalisation decision suggesting: "much depends on what happens during the international time-out period, particularly in terms of changes 
in management and/or ownership; the nature and strength of new re-entry influences; and how the re-entry process unfolds". Bell et al. (2003) introduce the term 'born-again globals', representing firms that had internationalised but subsequently pursued a domestic market strategy. They proceed to suggest that critical incidents such as a change in management or ownership, new capital or a change in scope of customers may affect international market re-entry decisions. Pauwels \& Matthyssens (2004) highlight learning and managerial flexibility in shaping strategies. As previously mentioned, the context of EM decision-making in this current investigation occurs following INVs' temporarily withdrawing from overseas markets, but not re-internationalising. The methodological approach undertaken follows.

\section{Methodology}

\subsection{Overview}

The benefits of using qualitative methods in EM studies to address 'how/why' issues has been acknowledged in earlier research (Gilmore, 2010). Moreover, as Woodside et al. (2005) suggest, asking practitioners for in-depth accounts of what happened and why, potentially helps them reflect and uncover nuances of what went right and what went wrong. This current study focused on semistructured interviews with owner-managers of sixteen INVs that had temporarily withdrawn from overseas markets and the approach undertaken was largely 'interpretivist' in nature. The study falls broadly under the umbrella term of a 'narrative inquiry' whereby interviewees reflected on their respective decision-making in respect of issues under investigation; that is, to understand the way they create meaning as narratives (Clandinin \& Connelly, 2004). The semi-structured interviews, undertaken in English, lasted up to one and a half hours.

Semi-structured interviews based on the template in Appendix 1 allowed the interviewer to engage in probing to ask 'how and why' issues; the approach was flexible to address questions in a different order plus allowed further discussion if any important issues arose or if further information was 
required. Shared meanings took place between the interviewer and interviewee to utilise practitioner terminology. Collection of other sources of data including company documents was limited due to perceived confidentiality. Table 1 summarises selected characteristics of the firms in this investigation. Data collection involved issues associated with the interviewee, their firm, the management team, decision-making regarding initial internationalisation, de-internationalisation, plus future strategy considerations. The term 'issues' follows from the work of Stake (1995) to avoid quantitative terminology such as 'variables.'

\section{Insert Table 1 Here}

\subsection{Data Collection}

It is emphasised that this qualitative investigation does not claim to involve case studies (as per Welch et al., 2011) due to the lack of 'thick-description' of multi-source data; hence the term 'cases' is restricted to meaning interviews with firms' owner-managers. Arriving at the appropriate number of cases ('interviews' is more appropriate terminology in this current investigation) to achieve a balance between theoretical saturation and cross-case comparison can be a challenge (Beverland \& Lindgreen, 2010). This study employed a non-probability purposive sampling strategy (Saunders et al., 2009). Data collection involved the recruitment of sixteen owner-managers of INVs that recently withdrew from overseas markets on a temporary basis using a snowballing process. Specifically, this was via practitioner networks associated with an institution in which one of the research team worked, plus other networks such as business incubators.

Interviewing key informants was a positive factor in this study despite data being from a single source, since other interviewees' perspectives would add limited value in respect of EM decisionmaking. Moreover, the interviewees responded with hindsight and hence this introduced the potential for retrospective bias. Triangulation look place where possible with certain secondary data such as websites and company documents, but this was limited as firms were relatively new. Start- 
up firms often have a high failure rate (Blank, 2013). Therefore, it was a challenge identifying relatively new firms that had internationalised rapidly, but had de-internationalised and undergoing re-evaluation of their strategies as opposed to going out of business.

'Boundary' conditions featured in this study (Stake, 1995); that is, factors that set the context of this UK based investigation. INVs from knowledge-intensive sectors such as those often labelled 'hightech' have a propensity to internationalise rapidly (Bell et al., 2004; Crick \& Crick, 2014; 2018a). Consistent with earlier research, having 'rapidly internationalised' in this study meant INVs needed to have entered an overseas market within 3 years of the start-up phase (see review articles such as Jones et al., 2011). All INVs were 'smaller-sized' businesses employing less than fifty staff; that is, on the lower end of the categorisation of a 'small-to-medium sized enterprise' (Storey, 1994).

\subsection{Analysis}

Sinkovics \& Alfoldi (2012) suggest that although studies often present qualitative research in a linear manner, suggesting a degree of predictable process and deductive reasoning, the actual process followed is iterative. 'Issues' in line with the terminology of Stake (1995) arose in this study in an iterative manner. Interviews involved asking decision-makers about issues arising from the review of the literature (Appendix 1 refers). Research of a 'how and why' nature was undertaken so further issues emerged during the investigation. Consequently, this study took an 'abductive' approach (Timmermans \& Tavory, 2012); that is, going back and forth between the primary and secondary data to produce inferences as patterns emerged. The iterative process enabled "progressive focusing" to be undertaken consistent with Stake (1995). Also consistent with Stake (1995) was the notion of "particularisation"; hence the researchers took account of factors like the context, narratives and personal engagement in the research.

Furthermore, Sinkovics \& Alfoldi (2012) highlight potential benefits of software to analyse data. The data in this investigation was small enough to allow the researchers to get 'close' to the data via 
manual coding. Specifically, manually coded data analysis took place around first order concepts, second order themes and aggregate dimensions as shown in Appendix 2; that is, similar but different to the 'Gioia methodology' (Gioia et al., 2013). It is emphasised that this study adopts an 'adapted' version of the Gioia methodology for diagrammatic clarity. In fact, the second order themes and aggregate dimension did not fully emerge from the empirical data in line with an inductive approach and instead from the 'abductive' research design that also involved the review of the literature. The second order themes arise from Morris et al. (2002) and the aggregate dimension relates to the research question.

Consideration of the "trustworthiness" (Lincoln \& Guba, 2000, Morrow, 2005) of the data took place, namely: credibility, transferability, dependability and confirmability. In part, such considerations helped establish the extent that findings arising from this investigation are transferable to other settings. For example, to enhance trustworthiness, this study set the previously mentioned "boundary", sharing of notes took place with interviewees, and discussions occurred among the researchers to allow them to agree the issues of importance under investigation during the 'abductive' approach undertaken.

\section{Findings}

\section{1 'Issues' Explaining De-Internationalisation}

A lack of preparation for internationalisation had influenced all the decision-makers' temporary withdrawal from serving overseas markets and not least due to a combination of EM issues related to lack of validation, such as, identifying customers' needs and especially adding value. In effect, all had internationalised too soon. Under these circumstances, all interviewees perceived it was useful to lose customers even on a temporary basis to enable the re-evaluation of EM strategies and minimise perceived affordable losses. However, perceptions towards the extent of the temporary nature of this withdrawal varied across interviewees, but they perceived the period to be short 
(discourse varied like a couple, few, several months); namely, while management teams reflected on decision-making before re-internationalisation was likely to re-commence. All interviewees had the broad objective to re-internationalise (somewhat consistent with causation decision-making). However, the manner for implementation remained undecided like choice of country, depending on perceived risk/reward considerations as opportunities arose (consistent with effectuation decisionmaking).

One underlying issue across all interviewees was a quick time period before funds ran out, namely, affordable losses in a financial sense. Exporting as a channel strategy for all firms enabled relative ease in market entry and subsequent exit decisions compared with other modes, such as subsidiaries. In re-evaluating EM decision-making, all interviewees perceived that the resources and capabilities of the management team in each firm was important if not inadequate; that is, being under-financed with limited experience and knowledge from prior employment together with the various networks utilised to date.

All interviewees mentioned that overseas sales served as a reference point to customers and potential stakeholders. Terminology differed like 'first mover' and a 'positive reputation', but gaining traction and scalability overseas signalled credibility in small global niche markets. Not least, breaking into the North American market that influenced decision-making in eight firms. For example, the interviewee in Firm 1 commented: "luck played a part as it's a small sector where most people (customers) know each other and I chatted to someone I knew and got the order but it was too soon and we just weren't ready. However, success there would have been a great indicator that we could expand to other countries". An underlying issue across all interviewees therefore related to perceived affordable losses in a non-financial sense; specifically, in respect of credibility in the small niche markets served, in addition to potential financial losses. 
In terms of EM characteristics, all of the interviewees were opportunity focused, proactive, looked to exploit innovation, leverage resources like capabilities, and considered risks/rewards (although perhaps not adequately). However, none had adequately prepared for internationalisation via a validation process (as per Osterwalder \& Pigneur, 2010; Blank, 2013; Gassmann et al., 2014) to take a customer-centric strategy or offer an effective value proposition. Risk/reward decisionmaking resulted in acceptance of serendipitous orders too soon. Discourse varied like the interviewee in Firm 5 suggesting: "we make our own luck by networking”, although that interviewee proceeded to add: "perhaps we were not that lucky with our choice!" A need therefore existed for all decision-makers to withdraw from overseas markets to minimise the previously mentioned negative perceptions from various stakeholders and potential financial losses; additionally, so further validation could be quickly undertaken.

Implicitly, all management teams initially considered particular aspects of EM behaviour, despite thoughts being relatively non-formalised, namely, without undertaking detailed research/validation. For example, to obtain initial funding from banks to supplement personal savings there was a need to show some limited understanding of customer characteristics, but not a value proposition. As the interviewee in Firm 10 commented: "we knew our target customers (segments) but clearly not what they wanted (value proposition)". The perceived affordable losses from an effectuation perspective in each firm were high in a monetary sense, since to varying degrees, members of the respective management teams had collateral such as re-mortgaging their houses if things went wrong with their business. As the interviewee in Firm 3 mentioned: "I re-mortgaged my house but it's a risk worth taking”. Given that each of the management teams was under-resourced financially and hence could afford relatively minimum outlays such as market research, there was a high degree of perceived risk towards various environmental pressures. The interviewee in Firm 7 commented: "of course 
research helps, but it is too expensive and time consuming, so we have to move quickly before we are out of funds".

Turning to stakeholders other than customers in more detail, internationalisation provided a potential credibility image of traction and scalability; however, the perceived importance varied across interviewees. Specifically, 'stakeholders' referred to those that interviewees may want to collaborate with, offer funding, or even acquire the interviewees' firms in the future including potential investors (the latter being evident in the eight firms commencing sales to North America). For example, the interviewee from Firm 15 suggested that: "it sent a message we were proactive and a good investment opportunity". This exemplified the common EM characteristics of all interviewees' proactive, innovative, risk-taking, opportunity seeking, and resource leveraging behaviour by internationalising to seek additional resources and capabilities as well as sales. Unfortunately, the rapid internationalisation without adequate validation (especially regarding customer requirements and a value proposition as facets of EM) potentially sent the wrong message to the organisations of interest. As the interviewee from Firm 12 commented: "we embarrassed ourselves a bit". Consequently, a need therefore existed to withdraw from overseas markets to minimise negative perceptions from potential network partners in addition to customers.

\subsection{Decision-Making and Potential Future Re-internationalisation}

The earlier mentioned negative experiences after a lack of initial preparation for internationalisation and perceptions towards 'affordable losses' in financial and non-financial terms, meant decisionmaking needed undertaking during the temporary (or 'time-out') period of de-internationalisation. Specifically, involving how to restore credibility with potential customers and network partners to allow subsequent re-internationalisation at a suitable future time. As previously alluded to, although revenue generation from customers in small international niche markets was an important issue, so 
was the ability to leverage resources and capabilities; that is, since none of the management teams had taken on investors at their early stage in their firm's start-up operations.

During the 'time-out' period, each of the interviewees re-evaluated the role of stakeholders and not least recognising that investors might be required to move the firm forward. As such, the 'time-out' period enabled decision-makers to minimise negative credibility issues after de-internationalisation took place. The interviewee in Firm 6 commented: "the right person can bring more to the table than money like their networks and the experience of working with others like us...they can open doors". All interviewees recognised the potential loss of aspects of control in decision-making if investors took an equity stake, despite the opportunities they may facilitate; however, that risk/reward decision in light of affordable losses was a potentially necessary requirement to assist enduring EM activities. The interviewee in Firm 10 commented that: "an investor will want to make money so we need to show there is market potential and we have a great team that the person can work with". This perception of interviewees to build/restore credibility included the potential for a later public share offering. The interviewee in Firm 11 suggested "an investor wants to make money so there may come a time I am forced to sell the business or perhaps go public if things work out". This was interesting since much of the EM literature focuses on entrepreneurs building and continuing in their business as opposed to those looking for 'exit' decisions. Hence the evolving 'objectives' of decision-makers in effectuation-oriented decision-making were important in guiding EM activities.

However, all the interviewees also recognised that even if their respective firms were to operate without investor support (to maintain control in the management team), particular actions were important to move their business forward and this included the need to re-internationalise as soon as practical. In short, this influenced the time-period for decision-making in learning from what went wrong (like lack of validation), seeking revenue streams and addressing credibility issues to restore 
a positive image among stakeholders. The interviewee in Firm 17 commented: "being successful overseas allows us to showcase our product so we need to get back out there (overseas) so customers know about us". The same interviewee proceeded to point out that: "we need to do our homework (validation) and undertake some damage control (restore credibility)".

\section{Discussion, Conclusions, Implications and Future Research}

\subsection{Discussion}

This current study is timely and important as it involves EM decision-making in INVs that rapidly de-internationalised and follows a recent call for more research (Yayla et al., 2018) given that earlier studies have concentrated on firms' continued overseas activities. The research question addressed in this study involved - what role does EM-oriented decision-making play for management teams in INVs that have rapidly withdrawn from overseas markets? The findings build on earlier research utilising an effectuation lens (Andersson, 2011; Gabrielsson \& Gabrielsson, 2013; Kalinic et al., 2014; Chetty et al., 2015; Galkina \& Chetty, 2015; Prashantham et al., 2018), although existing studies do not address the focus of this current investigation, hence providing a contextual as well as a theoretical contribution to knowledge. The findings of this current study broadly offer support for Sarasvathy (2001) namely, that all five facets of effectuation featured to some degree in entrepreneurs' decision-making and more specifically relating to internationalisation (Prashantham et al., 2018). However, a key issue related to entrepreneurs focusing on The Affordable Loss Principle' in the de-internationalisation decision, but in later considerations of planned reinternationalisation, other elements of effectuation became more evident. This suggests that particular elements of effectuation decision-making can be more prominent in particular contexts.

In terms of interviewees' reflections on their initial behaviour, the current study builds on existing research involving rapidly internationalising firms (Oviatt \& McDougall, 1994; Knight \& Cavusgil, 2004; Coviello, 2015; Crick \& Crick, 2018a). Findings suggest that risk/reward considerations 
(Sarasvathy, 2001) resulted in all management teams building on 'what' and 'who' they know in light of an unpredictable environment (Andersson, 2011). Studies such as Gabrielsson \& Gabrielsson (2013) and Crick \& Crick (2014) consider degrees of effectuation and causation based decision-making exhibited in behaviour, suggesting aspects of both can occur. In this current study, all interviewees knew 'broadly' what they wanted to achieve and why, but rushed into internationalisation without adequate preparation, accepting orders deemed unplanned or serendipitous (Spence \& Crick, 2006; Crick \& Crick, 2014; Mirvahed \& Morrish, 2017).

To grow their start-up firms, all interviewees perceived a need to balance risks/rewards in light of perceived affordable losses and move quickly via exports into small international market niches. For example, potential rewards involved revenue streams, gaining credibility in first mover status and recognition as a reference point for customers in other markets (Bell et al., 2004; Crick \& Crick, 2014; 2016; 2018a). Moreover, gaining traction and predictability of scalability acted as image creating behaviour for potential stakeholders, such as, investors to take the firm forward (Hewerdine et al., 2014; Crick \& Crick, 2018b). By de-internationalising, a key issue is therefore that different dimensions of the notion of 'affordable losses' exist, namely, in both financial (like profits/losses) and non-financial (such as credibility) terms.

Another key issue in this current study's findings suggested that in terms of EM behaviour in seeking potential rewards (as per Morris et al., 2002) all management teams were proactive, took risks, exploited innovation and engaged in opportunity-driven plus resource leveraging behaviour. In contrast, the key potential risks from accepting unplanned or serendipitous orders (as per Spence \& Crick, 2006; Crick \& Crick, 2014; Mirvahedi \& Morrish, 2017) included not understanding customers' requirements or adding enough value. A need therefore exists to consider all and not some of the facets of EM advocated by Morris et al. (2002). In essence, the net outcome involved decision-makers taking a product to a market too early and getting negative associations in a small 
niche where people often know and communicate with each other. As such, the timing of internationalisation may have been serendipitous, but not the outcome of receiving the order. Although conventional marketing literature advocates the merits of undertaking research, in reality, extensive information gathering can be too costly and time consuming for under-resourced start-up firms (Blank, 2013). In this current study, all interviewees had undertaken inadequate preparation such as 'build, measure and learn' and asking actual customers' perspectives in their customer discovery strategies (Osterwalder \& Pigneur, 2010; Ries, 2011; Blank, 2013; Gassmann et al., 2014).

In terms of interviewees' future objectives and the effect on decision-making, the study builds on earlier research to indicate that internationalisation is not always a forward moving process (Bell et al., 2003; Turner, 2012; Bernini et al., 2016; Yayla et al., 2018). This is important since relatively few studies exist concerning rapidly internationalising firms' continuing behaviour (MorganThomas \& Jones, 2009; Spence \& Crick, 2009; Ibeh et al., 2018). This current study supports the work of Hadjikhani (1997), Crick \& Chaudhry (2006) and Welch \& Welch (2009), to suggest a 'time-out' period after the decision to de-internationalise, for management teams to reflect on the way forward. This investigation explicitly highlighted the need to consider losing certain customers, even temporarily, to maintain and/or restore credibility among particular stakeholders in overseas product-market niches in addition to minimising financial losses.

\subsection{Conclusions}

This current study contributes to our understanding of risks/rewards in light of affordable losses associated with an effectuation-based approach (Sarasvathy, 2001); specifically, it offers insights into decision-making to facilitate enduring EM behaviour. The first conclusion arising from this investigation is that elements of effectuation-oriented decision-making are more important in certain contexts. The notion of perceived 'affordable losses' was prevalent following de- 
internationalisation. The second related conclusion is that there are different facets of 'affordable losses' related to financial (like profits) and non-financial (such as credibility) issues. The third conclusion is that adequate validation is important to avoid decision-makers acting on perceived rewards, like accepting serendipitous orders that can outweigh consideration of potential risks. It is important for owner-managers to undertake appropriate validation procedures associated with a customer discovery process (Osterwalder \& Pigneur, 2010; Ries, 2011; Blank, 2013; Gassmann et al., 2014) as a quick and low-cost risk minimisation strategy before limited resources are utilised.

The fourth conclusion is that in validation efforts, management teams need to consider the interrelationship between all and not just some of the facets of EM outlined by Morris et al (2002). For example, undertaking risk-taking behaviour, having a proactive mind-set, exploiting innovation, leveraging resources and engaging in opportunity driven behaviour was not enough in this current study. By moving too quickly without adequate preparation/validation procedures, a failure to understand customer needs/expectations in product-markets or create value, led to a risk/reward overseas market withdrawal decision and the need to re-evaluate strategies. Prashantham et al. (2018) identify 'internationalisation speed' as an important outcome variable; however, this current study highlights the performance consequence of that speed of overseas market entry needs careful consideration.

A fifth conclusion is that it can be useful under certain condition to lose customers even on a temporary basis and not least those where a negative initial encounter is experienced. For example, in favour of gaining other customers that offer more potential like perceived larger orders and ongoing relationships. Additionally, losing customers after negative encounters can help with credibility in respect of other stakeholders like potential investors. In fact, firms can go backwards from markets and consolidate operations via re-evaluating decision-making before moving forward (Bell et al, 2003). This may mean that effective marketing activities take place with different 
messages to create positive/credibility images with various stakeholders, namely, customers, potential investors and so on (Crick \& Crick, 2018b).

In summary, the previous points suggest that evolving, pivot strategies of de- and potential reinternationalising is potentially required (Bell et al., 2003; Yayla et al., 2018), unlike much of the existing INV literature that tends to consider a largely forward moving process (Oviatt \& McDougall, 1994; Knight \& Cavusgil, 2004; Coviello, 2015). If things do not initially work as expected, a brief period of reflection needs to take place, to identify and exploit opportunities based on further validation and risk/reward together with affordable loss considerations. Consistent with Hadjikhani (1997), Crick \& Chaudhry (2006) and Welch \& Welch (2009), a brief 'time-out' period allows reflection on learning, required validation activities, and a re-evaluation of strategies like reentry into overseas markets. Nevertheless, the affordable loss principle (Sarasvathy, 2001) means that evolving customer discovery strategies at that stage need rapid attention otherwise the burn rate of management teams' own finances may mean they are unable to recover from short-term negative experiences unless alternate resources are obtained. These conclusions lead to implications that follow.

\subsection{Implications}

In facilitating enduring EM activities, the first implication arising from this study involves management teams considering all and not some of the principles advocated by Morris et al. (2002). For example, being proactive, taking risks, leveraging resources, innovation focused and opportunity driven may only work up to a point. That is, the other EM issues identified by Morris et al. (2002) need recognising, namely, in balancing risks/rewards against affordable losses (Sarasvathy, 2001), do decision-makers also understand customers' needs and are able to add value? The inter-related seven EM facets mentioned by Morris et al (2002) need to feature in management teams' validation efforts and internationalisation considerations; that is, to minimise perceived 
rewards outweighing perceived risks. In other words, adequate validation efforts help in risk/reward considerations.

A re-evaluation of strategies may be required and especially after critical incidents (Bell et al., 2003; 2004). Therefore, a second implication is that management teams may only be able to take a business so far and key network partners (as per Bell et al., 2004; Crick \& Crick, 2018b) are possibly required to facilitate enduring EM activities. Effective 'marketing' approaches to potential stakeholders like investors, such as, demonstrating traction and scalability, is probably likely in addition to EM activities in serving customers. Being prepared to lose particular customers, even on a temporary basis, is important if strategies do not work out as anticipated (or hoped for) in the customer discovery process. Specifically, so decision-makers in start-up firms do not encounter perceived negative credibility issues among customers and network partners in small niche markets that are difficult to recover from and hence they cannot sustain enduring EM activities.

\subsection{Limitations and Future Research}

This study had certain limitations that are worthy of reflection and not least since Jones \& Rowley (2011) and Reuber et al. (2017) highlight the importance of 'context'. First, being UK based it is unknown whether there were cultural and institutional factors that affected the management teams and/or firms in the investigation. Second, being restricted to a number of smaller, knowledgeintensive firms with limited product portfolios, again offered potential limitations due to resource and sectoral considerations. Third, relying on owner-managers as interviewees provided a limitation on the perspective of key decision-makers, although in these smaller firms it is debatable what the perspectives of others would offer. Nevertheless, the interviewees had the benefit of hindsight and this introduced a degree of potential retrospective bias.

In taking the findings of this investigation further, avenues for future EM research include larger scale industry and cross-national studies, preferably using quantitative analysis, to build on the 
qualitative findings in this study. This might also include multiple perspectives such as various stakeholders' respective decision-making, including that of investors if they become part of an extended management team. Conversely, subject to facilitating access, individual case studies that offer an in-depth longitudinal perspective will help enhance understanding of decision-making in terms of processes followed together with contextual issues at a firm level. Findings will contribute to a more effective understanding of decision-making to facilitate the development of enduring EM activities. 


\section{References}

Ahmadi, H. \& O'Cass, A. (2016). The role of entrepreneurial marketing in new technology ventures first product commercialisation. Journal of Strategic Marketing, 24(1), 47-60.

Andersson, S. (2011). International entrepreneurship, born globals and the theory of effectuation. Journal of Small Business and Enterprise Development, 18(3), 627-643.

Arend, R.J., Sarooghi, H., \& Burkemper, A. (2015). Effectuation as ineffectual? Applying the 3E theory-assessment framework to a proposed new theory of entrepreneurship. Academy of Management Review, 40(4), 630-651.

Bell, J., Crick, D., \& Young, S. (2004). Small firm internationalisation and business strategy: an exploratory study of 'knowledge-intensive' and 'traditional' manufacturing firms in the UK. International Small Business Journal, 22(1), 23-56.

Bell, J., McNaughton, R.B., Young, S., \& Crick, D. (2003). Towards an integrative model of small firm internationalisation. Journal of International Entrepreneurship, 1(4), 339-362.

Bernini, M., Du, J., \& Love, J.H. (2016). Explaining intermittent exporting: exit and conditional reentry in export markets. Journal of International Business Studies, 47(9), 1058-1076.

Benito, G.R.G. \& Welch, L.S. (1997). De-internationalization. Management International Review, $37(2), 7-25$.

Beverland, M. \& Lindgreen, A. (2010). What makes a good case study? A positivist review of qualitative case research published in Industrial Marketing Management, 1971-2006. Industrial Marketing Management, 39(1), 56-63.

Bhuian, S.N., Menguc, B., \& Bell, S.J. (2005). Just entrepreneurial enough: the moderating effect of entrepreneurship on the relationship between market orientation and performance. Journal of Business Research, 58(1), 9-17.

Blank, S. (2013). Why the lean start-up changes everything. Harvard Business Review, 91(5), 6468. 
Chetty, S., Ojala, A., \& Leppaaho, T. (2015). Effectuation and foreign market entry of entrepreneurial firms. European Journal of Marketing, 49(9/10), 1436-1459.

Clandinin, D.J. \& Connelly, F.M. (2004). Narrative Inquiry: Experience and Story in Qualitative Research. San Francisco: Jossey-Bass Publishers.

Coviello, N.E. (2015). Re-thinking research on born globals. Journal of International Business Studies, 46(1), 17-26.

Crick, D. (2004). U.K. SMEs' decision to discontinue exporting: an exploratory investigation into practices within the clothing industry. Journal of Business Venturing, 19(4), 561-587.

Crick, D. \& Chaudhry, S. (2006). International marketing strategy in the electronics industry: a follow-up investigation of UK SMEs 18 months after the export withdrawal decision. Journal of Strategic Marketing, 14(3), 277-292.

Crick, D. \& Crick, J. (2014). The internationalization strategies of rapidly internationalizing hightech SMES: planned and unplanned activities. European Business Review, 26(5), 421-448.

Crick, D. \& Crick, J.M. (2016). The first export order: a marketing innovation revisited. Journal of Strategic Marketing, 24(2), 77-89.

Crick, J.M. \& Crick, D. (2018a). 'Lean start-up’ practices: initial internationalization and evolving business models. In Leonidou, L.C., Katsikeas, C.S., Samiee, S. \& Aykol, B. (Eds.) Advances in Global Marketing: A Research Anthology, Cham: Springer, 37-58, Forthcoming.

Crick, J.M. \& Crick, D. (2018b). Angel investors' predictive and control funding criteria: the importance of evolving business models. Journal of Research in Marketing and Entrepreneurship, 20(1), 34-56.

Eggers, F., Hansen, D.J., \& Davis, A.E. (2012). Examining the relationship between customer and entrepreneurial orientation on nascent firms' marketing strategy. International Entrepreneurship and Management Journal, 8(2), 203-222. 
Gabrielsson, P. \& Gabrielsson, M. (2013). A dynamic model of growth phases and survival in international business-to-business new ventures: the moderating effect of decision-making logic. Industrial Marketing Management, 42(8), 1357-1373.

Galkina, T. \& Chetty, S. (2015). Effectuation and networking in internationalizing SMEs. Management International Review, 55(5), 647-676.

Gassmann, O., Frankenberger, K., \& Csik, M. (2014). The Business Model Navigator. Harlow: FT Publishing.

Gilmore, A. (2010). Reflections on methodologies for research at the marketing/entrepreneurship interface. Journal of Research in Marketing and Entrepreneurship, 12(1), 11-20.

Gioia, D.A., Corley, K.G., \& Hamilton, A.L. (2013). Seeking qualitative rigor in inductive research: notes on the Gioia methodology. Organizational Research Methods, 16(1), 15-31.

Hadjikhani, A. (1997). A note on the criticisms against the internationalisation process model. Management International Review, 37(2), 43-66.

Hansen, D.J. \& Eggers, F. (2010). The marketing/entrepreneurship interface: a report on the “Charleston Summit”. Journal of Research in Marketing and Entrepreneurship, 12(1), 42-53.

Hansen, D.J., Giglierano, J. \& Whalen, P.S. (2018). "Guest editorial”. Journal of Research in Marketing and Entrepreneurship, 20(1), 2-9.

Hewerdine, L.J., Rumyantseva, M., \& Welch, C. (2014). Resource scavenging. Another dimension of the internationalisation pattern of high-tech SMEs. International Marketing Review, 31(3), 237-258.

Hills, G.E. \& Hultman, C.M. (2011). Academic roots: the past and present of entrepreneurial marketing. Journal of Small Business \& Entrepreneurship, 24(1), 1-10.

Hills, G.E., Hultman, C.M., \& Miles, M.P. (2008). The evolution and development of entrepreneurial marketing. Journal of Small Business Management, 46(1), 99-112. 
Hills, G.E. \& LaForge, R.W. (1992). Research at the marketing interface to advance entrepreneurship theory. Entrepreneurship Theory \& Practice, 16(3), 91-100.

Ibeh, K., Jones, M.V., \& Kuivalainen, O. (2018). Consolidating and advancing knowledge on the post-entry performance of international new ventures. International Small Business Journal, 36(7), 741-757.

Javalgi, R.G., Deligonul, S., Dixit, A., \& Cavusgil, S.T. (2010). International market re-entry: a review and research framework. International Business Review, 20(4), 377-393.

Johanson, J. \& Vahlne, J-E. (1977). The internationalization process of the firm - a model of knowledge development and increasing foreign market commitment. Journal of International Business Studies, 8(1), 23-32.

Jones, M.V. \& Coviello, N.E. (2005). Internationalisation: conceptualising an entrepreneurial process of behaviour in time. Journal of International Business Studies, 36(3), 284-303.

Jones, M.V., Coviello, N.E., \& Tang, Y.K. (2011). International entrepreneurship research (19892009): a domain ontology and thematic analysis. Journal of Business Venturing, 26(6), 632-659.

Jones, R. \& Rowley, J. (2011). Entrepreneurial marketing in small businesses: a conceptual exploration. International Small Business Journal, 29(1), 25-36.

Kalinic, I., Sarasvathy, S.D., \& Forza, C. (2014). 'Expect the unexpected': implications of effectual logic on the internationalization process. International Business Review, 23(3), 635-647.

Kilenthong, P., Hultman, C.M. \& Hills, G.E. (2016). Entrepreneurial marketing behaviours: impact of firm age, firm size and firm's founder. Journal of Research in Marketing and Entrepreneurship, 18(1), 127-145.

Knight, G.A. \& Cavusgil, S.T. (2004). Innovation, organization capabilities, and the born-global firm. Journal of International Business Studies, 35(2), 124-141. 
Liesch, P.W., Welch, L.S., \& Buckley, P.J. (2011). Risk and uncertainty in internationalisation and international entrepreneurship studies: review and conceptual development. Management International Review, 51(6), 851-873.

Lincoln, Y.S. \& Guba E.G. (2000). Paradigmatic controversies, contradictions, and emerging confluences. In Denzin NK, Lincoln YS (eds.). The Handbook of Qualitative Research. Beverly Hills, CA: Sage, 163-188.

McKelvie, A., Haynie, J.M., \& Gustavsson, V. (2011). Unpacking the uncertainty construct: implications for entrepreneurial action. Journal of Business Venturing, 26(3), 273-292.

Miles, M.P. \& Darroch, J. (2006). Large firms, entrepreneurial marketing processes, and the cycle of competitive advantage. European Journal of Marketing, 40(5/6), 485-501.

Miles, M., Gilmore, A., Harrigan, P., Lewis, G., \& Sethna, Z. (2014). Exploring entrepreneurial marketing. Journal of Strategic Marketing, 23(2), 94-111.

Mirvahedi, S. \& Morrish, S. (2017). The role of serendipity in opportunity exploration. Journal of Research in Marketing and Entrepreneurship, 19(2), 105-124.

Morgan-Thomas, A. \& Jones, M.V. (2009). Post-entry internationalization dynamics: differences between SMEs in the development speed of their international sales. International Small Business Journal, 27(1), 71-97.

Morrish, S.C. (2011). Entrepreneurial marketing: a strategy for the twenty-first century? Journal of Research in Marketing and Entrepreneurship, 13(2), 182-200.

Morris, M.H., Schindehutte, M., \& LaForge, R.W. (2002). Entrepreneurial marketing: a construct for integrating emerging entrepreneurship and marketing perspectives. Journal of Marketing Theory and Practice, 10(4), 1-19.

Morrish, S.C., Miles, M.P., \& Deacon, J.H. (2010). Entrepreneurial marketing: acknowledging the entrepreneur and customer-centric relationship. Journal of Strategic Marketing, 18(4), 303-316. 
Morrow, S.L. (2005). Quality and trustworthiness in qualitative research in counseling psychology. Journal of Counseling Psychology, 52(2), 250-260.

Osterwalder, A. \& Pigneur, Y. (2010). Business Model Generation. New Jersey: Wiley.

Oviatt, B.M. \& McDougall, P.P. (1994). Toward a theory of international new ventures. Journal of International Business Studies, 25(1), 45-64.

Pauwels, P. \& Matthyssens, P. (2004). Strategic flexibility in export expansion: growing through withdrawal. International Marketing Review, 21(4/5), 496-510.

Prashantham, S., Kumar, K., Bhagavatula, S., \& Sarasvathy, S.D. (2018). Effectuation, networkbuilding and internationalisation speed. International Small Business Journal, Forthcoming, https://doi.org/10.1177/0266242618796145.

Read, S., Sarasvathy, S.D., Dew, N., \& Wiltbank, R. (2016). Response to Arend, Sarooghi and Burkemper: co-creating effectual entrepreneurship research. Academy of Management Review, 41(July), 528-536.

Ries, E. (2011). The Lean Start-up. London: Penguin.

Reuber, A.B., Dimitratos, P., \& Kuivalainen, O. (2017). Editorial. Beyond categorization: new directions for theory development about entrepreneurial internationalization. Journal of International Business Studies, 48(4), 411-422.

Rose, G.M. \& Shoham, A. (2002). Export performance and market orientation: establishing an empirical link. Journal of Business Research, 55(3), 217-225.

Roundy, P.T. (2017). "Doing good" while serving customers. Charting the social entrepreneurship and marketing interface. Journal of Research in Marketing and Entrepreneurship, 19(2), 105124.

Saunders, M.N.K., Lewis, P., \& Thornhill, A. (2009). Research Methods for Business Students. London: Pearson. 
Sarasvathy, S.D. (2001). Causation and effectuation: toward a theoretical shift from economic inevitability to entrepreneurial contingency. Academy of Management Review, 26(2), 243-263.

Sinkovics, R.R. \& Alfoldi, E.A. (2012). Progressive focusing and trustworthiness in qualitative research: the enabling role of computer-assisted qualitative data analysis software (CAQDAS). Management International Review, 52(6), 817-845.

Spence, M. \& Crick, D. (2006). A comparative investigation into the internationalization of Canadian and UK high-tech SMEs. International Marketing Review, 22(5), 524-548.

Spence, M. \& Crick, D. (2009). An exploratory study of Canadian international new venture firms' development in overseas markets. Qualitative Market Research: An International Journal, 12(2), 208-233.

Stake, R.E. (1995). The Art of Case Study Research. Thousand Oaks, CA: Sage.

Storey, D.J. (1994). Understanding the Small Business Sector. London: Routledge.

Timmermans, S. \& Tavory, I. (2012). Theory construction in qualitative research from grounded theory to abductive analysis. Sociological Theory, 30(3), 167-186.

Turner, C. (2012). De-internationalisation: towards a co-evolutionary framework. European Business Review, 24(2), 92-105.

Vahlne, J-E., Hamberg, M., \& Schweizer, R. (2017). Management under uncertainty - the unavoidable risk-taking. Multinational Business Review, 25(2), 91-109.

Welch, C., Piekkari, R., Plakoyiannaki, E., \& Paavilainen-Mantymaki, E. (2011). Theorising from case studies: towards a pluralist future for international business research. Journal of International Business Studies, 42(5), 740-762.

Welch, C. \& Welch, L.S. (2009). Re-internationalisation: exploration and conceptualisation. International Business Review, 18(6), 567-577

Welch, L.S. \& Wiedersheim-Paul, F. (1980). Initial exports - a marketing failure. Journal of Management Studies, 17(3), 333-344. 
Whalen, P.S. \& Akaka, M.A. (2016). A dynamic market conceptualization for entrepreneurial marketing: the co-creation of opportunities. Journal of Strategic Marketing, 24(1), 61-75.

Whalen, P., Uslay, C., Pascal, V.J., Omura, G., McAuley, A., Kasouf, C.J, Jones, R., Hultman, C.M., Hills, G.E., Hansen, D.J., Gilmore, A., Giglierano, J., Eggers, F., \& Deacon, J. (2016). Anatomy of competitive advantage: towards a contingency theory of entrepreneurial marketing. Journal of Strategic Marketing, 24(1), 5-19.

Woodside, A.G., Pattinson, H.M., \& Miller, K.E. (2005). Advancing hermeneutic research for interpreting interfirm new product development. Journal of Business \& Industrial Marketing, 20(7), 364-379.

Yang, M. \& Gabrielsson, P. (2017). Entrepreneurial marketing of international high-tech businessto-business new ventures: a decision-making process perspective. Industrial Marketing Management, 64(July), 147-160.

Yayla, S., Yeniyurt, S., Uslay, C., \& Cavusgil, E. (2018). The role of market orientation, relational capital, and internationalization speed in foreign market exit and re-entry decisions under turbulent conditions. International Business Review, 27(6), 1105-1115.

Zhu, Z. \& Matsuno, K. (2016). Entrepreneurial proclivity: its environmental conditions and growth consequences. Journal of Strategic Marketing, 24(1), 20-33. 
Table 1: Selected Profiles of the Firms

\begin{tabular}{|c|c|c|c|c|}
\hline Firm & Internationalisation Path & & & \\
\hline & Time to Internationalise & First Region & Entry Mode & Comments \\
\hline Firm 1 & Year 1 & North America & Exports & $\begin{array}{l}\text { No validation only superficial research and could not add value as the } \\
\text { technology was not required after the first initial order. }\end{array}$ \\
\hline Firm 2 & Year 2 & Europe & Exports & $\begin{array}{l}\text { Informal research including contacts from prior employment but while the } \\
\text { technology was good it was expensive so little prospect of repeat orders. }\end{array}$ \\
\hline Firm 3 & Year 2 & Europe & Exports & $\begin{array}{l}\text { Informal research including contacts from prior employment but } \\
\text { internationalised before the technology was ready as MVP had problems. }\end{array}$ \\
\hline Firm 4 & Year 1 & Europe & Exports & $\begin{array}{l}\text { No validation only superficial research and the technology that passed the } \\
\text { MVP stage experienced problems. }\end{array}$ \\
\hline Firm 5 & Year 2 & Europe & Exports & $\begin{array}{l}\text { No validation only superficial research and the technology did not add value } \\
\text { as a competitor launched a modified, less expensive version. }\end{array}$ \\
\hline Firm 6 & Year 2 & North America & Exports & $\begin{array}{l}\text { Informal research including contacts from prior employment but } \\
\text { internationalised before the technology was ready as MVP had problems. }\end{array}$ \\
\hline Firm 7 & Year 1 & Europe & Exports & $\begin{array}{l}\text { Informal research including contacts from prior employment but could not } \\
\text { add value as the technology was not required after the first initial order. }\end{array}$ \\
\hline Firm 8 & Year 1 & Europe & Exports & $\begin{array}{l}\text { Informal research including contacts from prior employment but customers } \\
\text { perceived the technology as too complicated. }\end{array}$ \\
\hline Firm 9 & Year 2 & Europe & Exports & $\begin{array}{l}\text { Informal research including contacts from prior employment but } \\
\text { internationalised before the technology was ready as MVP had problems. }\end{array}$ \\
\hline Firm 10 & Year 2 & North America & Exports & $\begin{array}{l}\text { No validation only superficial research and the technology that passed the } \\
\text { MVP stage experienced problems. }\end{array}$ \\
\hline Firm 11 & Year 1 & North America & Exports & $\begin{array}{l}\text { Informal research including with contacts from prior employment but while } \\
\text { the technology was good, it was expensive so little prospect of repeat orders. }\end{array}$ \\
\hline Firm 12 & Year 1 & North America & Exports & $\begin{array}{l}\text { No validation only informal research and the technology that passed the } \\
\text { MVP stage experienced problems. }\end{array}$ \\
\hline Firm13 & Year 2 & North America & Exports & $\begin{array}{l}\text { No validation only superficial research and could not add value as the } \\
\text { technology was not required after the first initial order. }\end{array}$ \\
\hline Firm 14 & Year 2 & North America & Exports & $\begin{array}{l}\text { No validation only superficial research and could not add value as the } \\
\text { technology was not required after the first initial order. }\end{array}$ \\
\hline Firm 15 & Year 2 & North America & Exports & $\begin{array}{l}\text { Informal research including contacts from prior employment but customers } \\
\text { perceived the technology as too complicated. }\end{array}$ \\
\hline Firm 16 & Year 1 & Europe & Exports & $\begin{array}{l}\text { No validation only superficial research and the technology that passed the } \\
\text { MVP stage experienced problems. }\end{array}$ \\
\hline
\end{tabular}




\section{Appendix 1: Interview Schedule}

\begin{tabular}{|c|c|}
\hline Research Issues & Sub-Issues \\
\hline Company background & $\begin{array}{l}\text { - Interviewee and management team's characteristics } \\
\text { - Year founded } \\
\text { - Sector } \\
\text { - Employees }\end{array}$ \\
\hline $\begin{array}{l}\text { Owner/manager's experience } \\
\text { and of management team }\end{array}$ & $\begin{array}{l}\text { - Education/training (if not answered above) } \\
\text { - Experience overseas } \\
\text { - Industry experience }\end{array}$ \\
\hline Internationalisation & $\begin{array}{l}\text { - Reasons - explore risks/rewards against objectives } \\
\text { - Research/validation - explore business model factors } \\
\text { - Where and when } \\
\text { - How - like entry mode } \\
\text { - First country or countries } \\
\text { - What happened - explore EM issues }\end{array}$ \\
\hline De-internationalisation & $\begin{array}{l}\text { - When } \\
\text { - Why/what factors - explore risks/rewards against } \\
\text { objectives } \\
\text { - Who decided } \\
\text { - Timescale } \\
\text { - Key learning and effect on business model factors } \\
\text { - Explore EM issues }\end{array}$ \\
\hline Influence on firm & $\begin{array}{l}\text { - Revised objectives - link to business model } \\
\text { - Role of other people/organisations on decision- } \\
\text { making } \\
\text { - Performance (stress non-confidential and link to } \\
\text { objectives) } \\
\text { - Future EM strategy aspirations (like re- } \\
\text { internationalisation) }\end{array}$ \\
\hline
\end{tabular}




\section{Examples of first-order themes}

\section{"Orders in the US can lead to others elsewhere"}
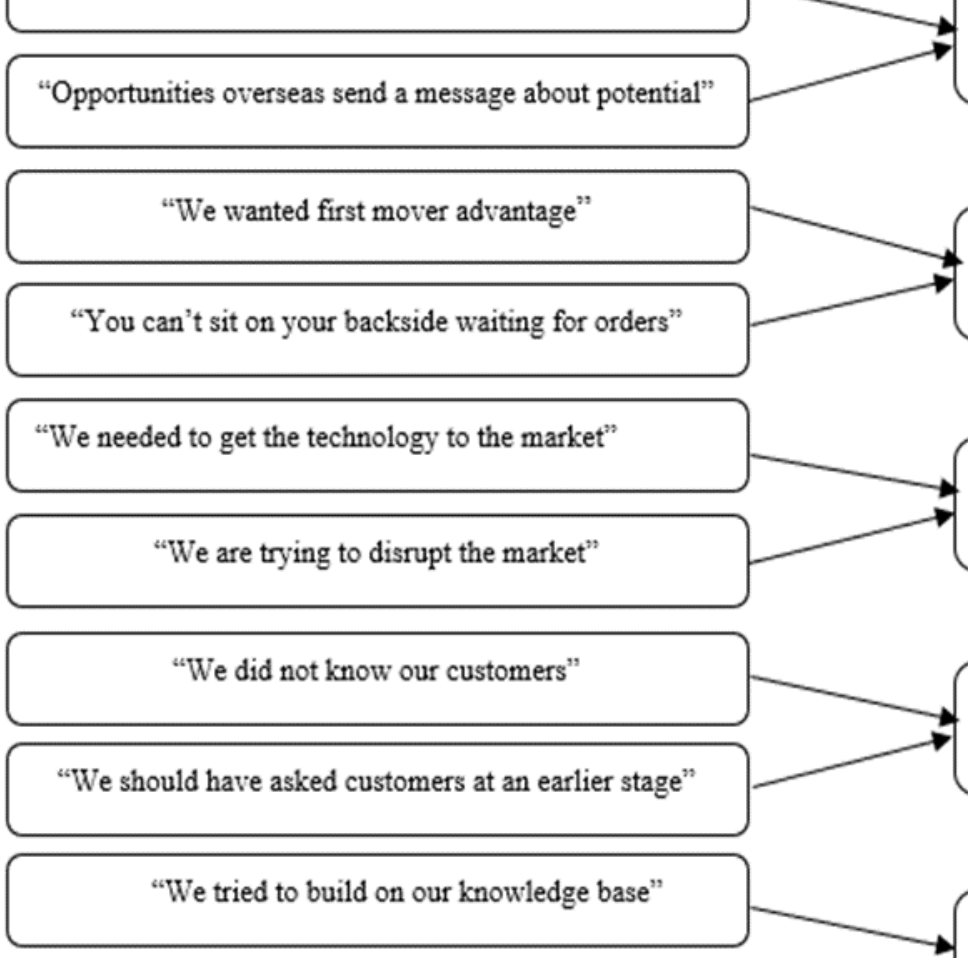

"Our IP offers us an example despite our small size"

"We did not offer what the customer wanted"

"On reflection what we offered was not of value"

"We took the risk and got the timing wrong"

"Business is like gambling and you can't always win"

\section{Pre-defined second-order themes}

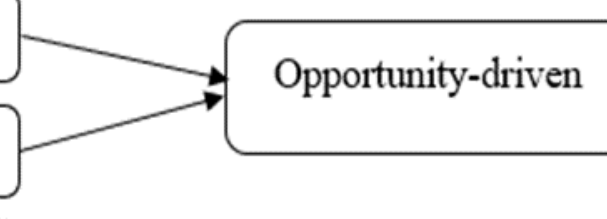


Decision-making should account for all facets of entrepreneurial marketing.

Rapid internationalisation without validation can have negative performance outcomes.

Losing customers can facilitate enduring entrepreneurial marketing activities.

Certain elements of effectuation can dominate decision-making in specific contexts.

Different dimensions exist of entrepreneurs' perceived 'affordable loss'. 